\title{
Ruthenium nanoparticles supported on mesoporous MCM-41 as an efficient and reusable catalyst for selective oxidation of arenes under ultrasound irradiation
}

\author{
Alireza Khorshidi * \\ Department of Chemisty, Faculty of Sciences, University of Guilan, P. O. Box 41335-1914, Guilan, Rasht, Iran
}

\section{A R T I C L E I N F O}

Article history:

Received 9 October 2015

Accepted 24 October 2015

Published 5 January 2016

\section{Keywords:}

Nanoparticle

Ultrasound

Ruthenium

Arene oxidation

MCM-41

\begin{abstract}
A B S T R A C T
Mesoporous MCM-41 was used as a support for the uniform dispersion of ruthenium nanoparticles having an average particle size of $\sim 5 \mathrm{~nm}$. The obtained nanocomposite, MCM-41-Ru, was characterized using inductively coupled plasma, transmission electron microscopy, energy dispersive X-ray analysis, X-ray diffraction, and BET surface area measurements. The material was employed as an efficient and recyclable catalyst in the ultrasound-assisted oxidation of arenes. It was observed that ultrasound irradiation in combination with $\mathrm{KBrO}_{3}$ as the oxidant, in the presence of MCM-41-Ru nanoparticles, accelerates the oxidation reaction to afford the desired products in good yields. The recovered catalyst retained activity for successive runs, with a continuous change in the nature of its active sites.
\end{abstract}

(C) 2016, Dalian Institute of Chemical Physics, Chinese Academy of Sciences. Published by Elsevier B.V. All rights reserved.

\section{Introduction}

Applying nanoparticles in the manufacture of fine chemicals is currently an area of intense interest because of their unique features. Such features include electrical and magnetic properties, selectivity and, above all, reusability, which is a valuable property in applications such as drug delivery, green chemistry, and sensors [1-8]. Oxidation products of arenes have also attracted attention because of their notoriety as carcinogens and their usefulness as chelating ligands and as intermediates in the preparation of fused-ring molecules [9-13]. Many investigations have reported the development of simple and efficient methods for direct oxidation of arenes [14-16]. Typically, oxidation of arenes in the presence of a metal oxidant, such as chromium(VI) oxide, requires a large excess of the oxidant. Metal residues, however, are environmentally undesirable and often cause difficulties during reaction and work-up. Bio- transformation of arenes has also been reported. One study by Obbard's group [17] reported that the white rot fungus oxidation of polycyclic aromatic hydrocarbons had a limited applicability to higher arenes. Hence, developing new methods for selective oxidation of arenes, which utilizes a metal catalyst in combination with an appropriate stoichiometric oxidant, is in demand. Direct oxidation to diones has been reported in low yields by using osmium tetroxide, which is highly toxic [18]. $\mathrm{RuO}_{4}$ species generated in situ, together with sodium periodate $\left(\mathrm{NaIO}_{4}\right)$ as a cheap and readily available oxidant, provides a promising alternative for such oxidations [19-23]. Harris' group [24] reported a one-step synthesis of pyrene-4,5-diones and pyrene-4,5,9,10-tetraones by using $\mathrm{RuCl}_{3}$ as the catalyst and $\mathrm{NaIO}_{4}$ as the oxidant. We studied their protocols for generating various arenes and heteroaromatic compounds, which used ultrasound irradiation to overcome the prolonged reaction time, and although the results were promising [25], the

\footnotetext{
* Corresponding author. Tel: +98-911 339 7159; Fax: +98-13 333332 62; E-mail: khorshidi@guilan.ac.ir This work was supported by the Research Council of University of Guilan. DOI: 10.1016/S1872-2067(15)61001-4 | http://www.sciencedirect.com/science/journal/18722067 | Chin. J. Catal., Vol. 37, No. 1, January 2016
} 
catalyst was not recoverable. Furthermore, previous studies on ruthenium-catalyzed oxidation of arenes yielded either dicarboxylic acids, tetracarboxylic acids, or diols [26-28]. Herein, we report an improvement to the limitations of our previous report by using ruthenium nanoparticles dispersed on mesoporous MCM-41 to circumvent the difficulty in catalyst recovery. The catalyst was found to be efficient and recyclable in the ultrasound-assisted oxidation of aromatic compounds.

\section{Experimental}

\subsection{Materials}

All materials were purchased from Merck and used without further purification. Pure-silica MCM-41 was synthesized according to the literature [29].

\subsection{Preparation of MCM-41-Ru nanoparticles}

$\mathrm{RuCl}_{3} \cdot 3 \mathrm{H}_{2} \mathrm{O}$ (51.8 mg) was added to a suspension of MCM-41 (1.0 g) in $10 \mathrm{~mL}$ of absolute ethanol under $\mathrm{N}_{2}$ atmosphere in a two-necked round bottom flask. Thereafter, a $\mathrm{NaBH}_{4}$ solution ( $0.2 \mathrm{~mol} / \mathrm{L}$ in ethanol, excess) was added drop-wise under vigorous stirring using a magnetic stirrer for a period of $2 \mathrm{~h}$. The entire reaction mixture was stirred overnight to stabilize the Ru nanoparticles according to the MCM-41 framework. The obtained dark-gray product (MCM-41-Ru) was filtered and washed with ethanol followed by drying at $150{ }^{\circ} \mathrm{C}$ overnight.

\subsection{Characterization of catalyst}

IR spectra were recorded on a Shimadzu FTIR-8400S spectrometer. ${ }^{1} \mathrm{H}$ NMR spectra and ${ }^{13} \mathrm{C}$ NMR spectra were obtained on a Bruker DRX-500 (or 125) Advance Spectrometer. Chemical shifts were expressed in ppm downfield from tetramethylsilane as the internal standard. Melting points were measured on a Büchi®B-540 melting point tube and were uncorrected. Elemental analyses were conducted using a Carlo-Erba EA1110 CNNO-S analyzer, and the results agreed with the calculated values. X-ray powder diffraction (XRD) measurements were performed using a Philips diffractometer with monochromatic $\mathrm{Cu} K_{\alpha}$ radiation. Ultrasonication was performed in a Techno-Gaz Tecna 3 ultrasonic cleaner, which subjected samples to a frequency of 50-60 kHz under a typical power of 250 $\mathrm{W}$. The reaction flask was positioned within the water bath of the ultrasonic cleaner at a temperature, controlled by the device. Analytical gas chromatography (GC) evaluation of product mixtures was performed on a gas chromatograph (split/splitless injector, CP Sil 8CB column, FID assembly; Teif Gostar Faraz Co., Iran). Transmission electron micrographs were obtained using a Philips MC-10 transmission electron microscope (TEM) employing an acceleration voltage of $80 \mathrm{kV}$. BET measurements were acquired using a Sibata surface area apparatus 1100 . Inductively coupled plasma analysis was conducted on a Labtam 8440 Plasma Lab.

\subsection{Ultrasound assisted MCM-41-Ru catalyzed oxidation of}

arenes

A 20-mL flask was charged with $\mathrm{CH}_{2} \mathrm{Cl}_{2}(5 \mathrm{~mL}), \mathrm{H}_{2} \mathrm{O}(5 \mathrm{~mL})$, $\mathrm{CH}_{3} \mathrm{CN}$ (5 mL), chrysene (228.3 mg, $1 \mathrm{mmol}$ ), and $\mathrm{KBrO}_{3}(0.5 \mathrm{~g}$, $2.99 \mathrm{mmol}$ ). MCM-41-Ru (75 mg) was added into the flask, and the dark suspension was irradiated at room temperature for 1 h. The catalyst was separated from the reaction medium by filtration and washed with water and acetone, and then dried at $150{ }^{\circ} \mathrm{C}$ overnight. The reaction mixture was poured into $50 \mathrm{~mL}$ of water, and the organic phase was separated. The aqueous phase was extracted with $\mathrm{CH}_{2} \mathrm{Cl}_{2}(3 \times 10 \mathrm{~mL})$. The $\mathrm{CH}_{2} \mathrm{Cl}_{2}$ extracts were combined with the organic phase, washed with brine $(3 \times 10 \mathrm{~mL})$, and dried over anhydrous sodium sulfate to yield a dark orange solution. The solution was concentrated under reduced pressure, and the mixture was purified by preparative thin-layer chromatography ( $n$-hexane $/$ ethyl acetate $=$ 10/3), providing chrysene-5,6-dione as the major product and 2-(2-formylphenyl)-1-naphthaldehyde as the side product. The same procedure was also used for the reactions of other arene substrates.

\subsection{Characterization data for selected products}

Chrysene-5,6-dione (4a): Orange crystals, m.p. = 189-191 ${ }^{\circ} \mathrm{C}$; IR (KBr): $v\left(\mathrm{~cm}^{-1}\right)=660,713,756,835,957,1040,1086$, 1250, 1298, 1364, 1447, 1483, 1595, 1662, 1693, 1767, 2927, 3066; ${ }^{1} \mathrm{H}$ NMR $\left(500 \mathrm{MHz}, \mathrm{CDCl}_{3}, 25^{\circ} \mathrm{C}\right): \delta=7.52(\mathrm{t}, J=7.5 \mathrm{~Hz}$, $1 \mathrm{H}), 7.60(\mathrm{t}, J=7.7 \mathrm{~Hz}, 1 \mathrm{H}), 7.74(\mathrm{t}, J=8.5 \mathrm{~Hz}, 1 \mathrm{H}), 7.77(\mathrm{t}, J=8.1$ $\mathrm{Hz}, 1 \mathrm{H}), 7.87(\mathrm{~d}, J=7.9 \mathrm{~Hz}, 1 \mathrm{H}), 8.12$ (d, $J=8.6 \mathrm{~Hz}, 2 \mathrm{H}), 8.18(\mathrm{~d}, J$ $=7.4 \mathrm{~Hz}, 1 \mathrm{H}), 8.20(\mathrm{~d}, J=8.6 \mathrm{~Hz}, 1 \mathrm{H}), 9.43(\mathrm{~d}, J=8.8 \mathrm{~Hz}, 1 \mathrm{H})$ ppm; ${ }^{13} \mathrm{C}$ NMR $\left(125 \mathrm{MHz}, \mathrm{CDCl}_{3}, 25^{\circ} \mathrm{C}\right): \delta=121.54,125.64$, 126.34, 127.62, 128.09, 129.09, 130.32, 130.45, 131.09, 131.28, $132.67,134.23,136.49,137.06,137.78,138.29,182.45,184.63$ ppm; Anal. calcd. for $\mathrm{C}_{18} \mathrm{H}_{10} \mathrm{O}_{2}$ (\%): C 83.71, H 3.90, $\mathrm{O}$ 12.39; found: C 83.75, H 3.88 .

2-(2-Formylphenyl)-1-naphthaldehyde (4b): Yellow crystals, m.p. $=214-216^{\circ} \mathrm{C}$; IR (KBr): $v\left(\mathrm{~cm}^{-1}\right)=648,709,764,831$, $954,1057,1196,1354,1429,1504,1591,1686,2754,2852$, 2926, 3057; ${ }^{1} \mathrm{H}$ NMR (500 MHz, $\left.\mathrm{CDCl}_{3}, 25^{\circ} \mathrm{C}\right): \delta=7.46(\mathrm{~d}, J=8.2$ $\mathrm{Hz}, 2 \mathrm{H}), 7.67-7.81(\mathrm{~m}, 3 \mathrm{H}), 7.79(\mathrm{t}, J=8.0 \mathrm{~Hz}, 1 \mathrm{H}), 8.01(\mathrm{~d}, J=$ $8.05 \mathrm{~Hz}, 1 \mathrm{H}), 8.15$ (d, $J=8.3 \mathrm{~Hz}, 2 \mathrm{H}), 9.32(\mathrm{~d}, J=8.6 \mathrm{~Hz}, 1 \mathrm{H}$ ), 9.92 (s, 1H), 10.23 (s, 1H) ppm; ${ }^{13} \mathrm{C}$ NMR (125 MHz, CDCl 3,25 $\left.{ }^{\circ} \mathrm{C}\right): \delta=126.26,127.81,128.95,128.97,129.15,129.43,130.18$, 130.28, 130.86, 132.55, 133.77, 133.91, 134.40, 134.97, 142.49, 144.65, 191.27, 193.61 ppm; Anal. calcd. for $\mathrm{C}_{18} \mathrm{H}_{12} \mathrm{O}_{2}$ (\%): C 83.06, H 4.65, 0 12.29; found: C 82.09, H 4.66.

Pyrene-4,5-dione (5a): Orange crystals, m.p. $=299-302{ }^{\circ} \mathrm{C}$; IR (KBr): $v\left(\mathrm{~cm}^{-1}\right)=703,837,1267,1350,1429,1517,1610$, 1663, 2850, 2923, 3068; ${ }^{1} \mathrm{H}$ NMR (500 MHz, $\left.\mathrm{CDCl}_{3}, 25^{\circ} \mathrm{C}\right): \delta=$ $7.52(\mathrm{t}, J=7.6 \mathrm{~Hz}, 2 \mathrm{H}), 7.61(\mathrm{~s}, 2 \mathrm{H}), 7.95(\mathrm{~d}, J=7.4 \mathrm{~Hz}, 2 \mathrm{H}), 8.18$ $(\mathrm{d}, J=6.8 \mathrm{~Hz}, 2 \mathrm{H}) \mathrm{ppm} ;{ }^{13} \mathrm{C} \mathrm{NMR}\left(125 \mathrm{MHz}, \mathrm{CDCl}_{3}, 25^{\circ} \mathrm{C}\right): \delta=$ 127.52, 128.21, 128.44, 130.11, 130.21, 132.22, 136.04, 180.50 ppm; Anal. calcd. for $\mathrm{C}_{16} \mathrm{H}_{8} \mathrm{O}_{2}$ (\%): C 82.75, $\mathrm{H}$ 3.47, $\mathrm{O}$ 13.78; found: C 82.72, H 3.45 .

Pyrene-4,5,9,10-tetraone (6a): Orange crystals, m.p. $>350$ ${ }^{\circ} \mathrm{C}$; IR (KBr): $v\left(\mathrm{~cm}^{-1}\right)=711,808,908,1054,1276,1336,1421$, $1446,1562,1676,2923$; ${ }^{1} \mathrm{H}$ NMR (500 MHz, DMSO-d $\left.6,25^{\circ} \mathrm{C}\right): \delta$ 


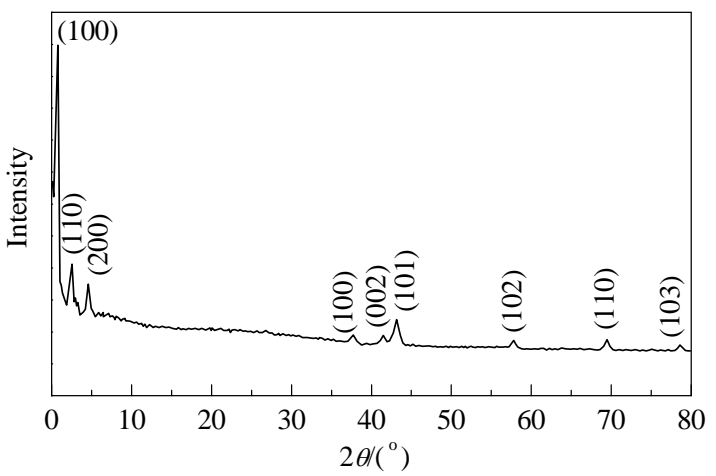

Fig. 1. XRD pattern of MCM-41-Ru nanoparticle composite.

$=7.62(\mathrm{t}, J=7.7 \mathrm{~Hz}, 2 \mathrm{H}), 8.38(\mathrm{~d}, J=7.7 \mathrm{~Hz}, 4 \mathrm{H}) \mathrm{ppm} ;{ }^{13} \mathrm{C} \mathrm{NMR}$ (125 MHz, DMSO- $\left.d 6,25^{\circ} \mathrm{C}\right): \delta=131.29,131.44,134.80,136.82$, 178.13 ppm; Anal. calcd. for $\mathrm{C}_{16} \mathrm{H}_{6} \mathrm{O}_{4}$ (\%): C 73.29, H 2.31, $\mathrm{O}$ 24.41; found: C 73.23, H 2.30.

\section{Results and discussion}

Deposition of Ru nanoparticles over the surface of mesoporous MCM-41 was performed via a facile procedure, and the MCM-41-Ru composite was first characterized by XRD analysis. The MCM-41-Ru diffractogram (Fig. 1) displays peaks attributed to both the mesoporous structure and $\mathrm{Ru}$ nanoparticles. Peak reflections related to the siliceous mesoporous structure, at $2 \theta=1.5^{\circ}-10^{\circ}$ and indexed as the (100), (110), and (200) crystallographic planes, are characteristic of MCM-41 [29]. The $\mathrm{Ru}$ nanoparticles possess peak reflections at $2 \theta=38.4^{\circ}, 42.2^{\circ}$, $44.0^{\circ}, 58.2^{\circ}, 69.6^{\circ}$, and $78.4^{\circ}$ corresponding to the diffractions (100), (002), (101), (102), (110), and (103) planes, respectively, which are identical to the hexagonally close-packed (hcp) $\mathrm{Ru}$ metal (ICDD-JCPDS card No. 06-0663).

TEM revealed an abundance of ultrafine spherical particles (Fig. 2), which were homogeneously dispersed over the surface of the mesoporous structure and possessed a narrow particle size distribution averaging $\sim 5 \mathrm{~nm}$ according to the corresponding particle size analysis chart. EDS analysis further confirmed the presence of $\mathrm{Ru}$ in the composite (Fig. 2). The $\mathrm{Ru}$ content of $1.983 \%$, however, was determined using inductively

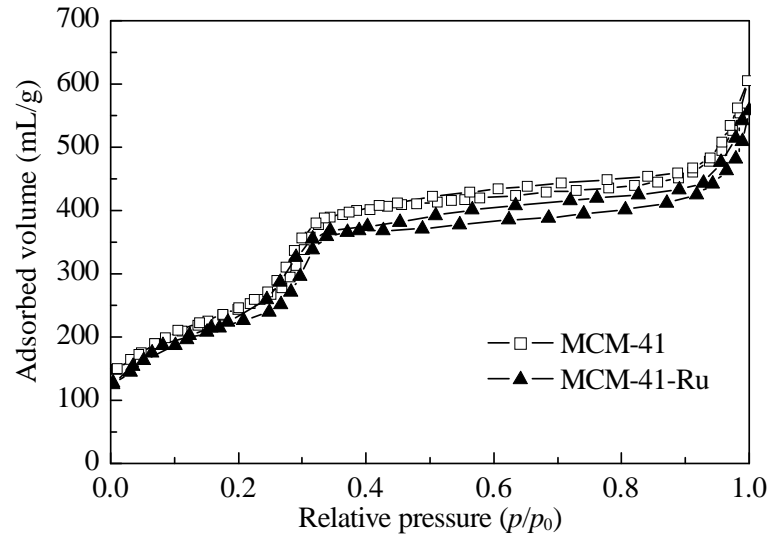

Fig. 3. $\mathrm{N}_{2}$ adsorption-desorption isotherms of MCM-41 and MCM-41-Ru.

coupled plasma.

Deposition of the Ru nanoparticles, however, did not significantly affect the textural properties of the support. The $\mathrm{N}_{2}$ adsorption-desorption isotherm of the calcined MCM-41 displays typical type-IV behavior with an observed H1-type hysteresis loop. The inflection point as given by the sharp inflection point over a narrow relative pressure indicates a highly ordered mesoporous material (Fig. 3). Conversely, the MCM-41-Ru sample showed a similar pattern (Fig. 3); however, a slight decrease in the uptake of adsorbed $\mathrm{N}_{2}$ is observed, which can be attributed to the reduced surface area $\left(897 \mathrm{~m}^{2} / \mathrm{g}\right.$ vs. 930 $\mathrm{m}^{2} / \mathrm{g}$ ). The small hysteresis loop is present at the same relative pressures, $p / p_{0}$, between 0.25 and 0.35 , indicating that no considerable pore-filling effect occurred after deposition of the $\mathrm{Ru}$ nanoparticles over the surface of MCM-41.

The characterized composite was then employed as a catalyst with naphthalene selected as the substrate. A set of optimization experiments were conducted to determine the optimum reaction conditions with respect to the catalyst loading, solvent, temperature, and oxidant. These results are summarized in Table 1.

The presence of MCM-41-Ru is necessary for the selective transformation of naphthalene to phthalaldehyde. In the absence of the catalyst, even after $12 \mathrm{~h}$, only trace concentrations of naphthalene-1,4-dione and dihydronaphthalene-1,2-diole
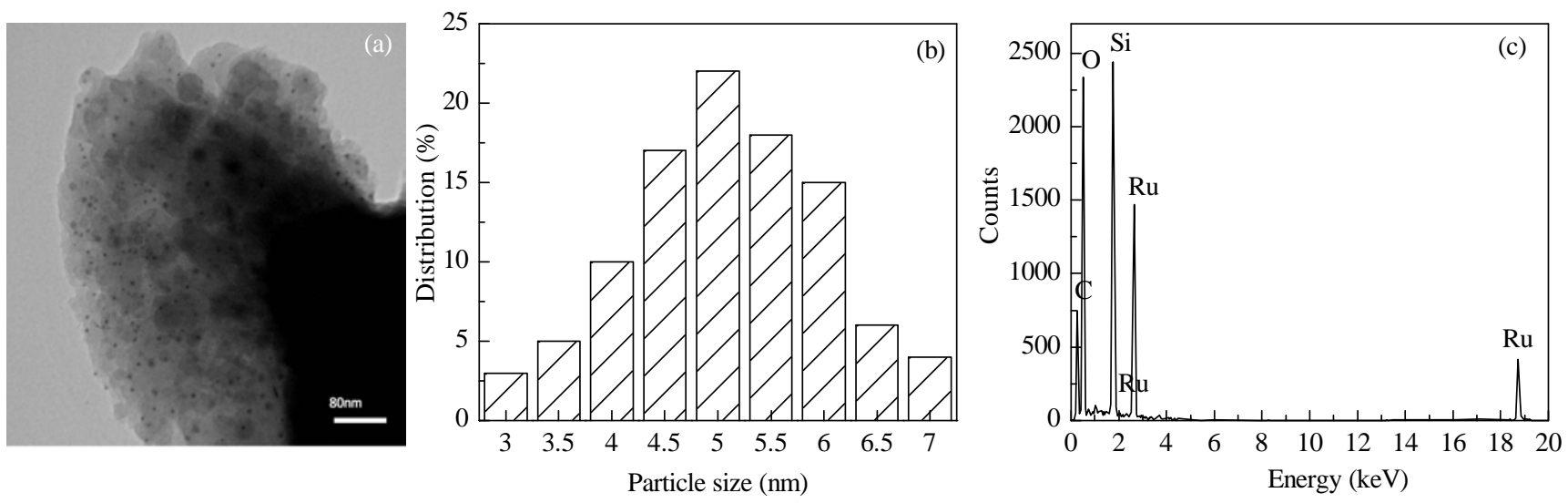

Fig. 2. TEM image of the MCM-41-supported Ru nanoparticles (a), corresponding particle size distribution (b), and EDS spectrum (c). 
Table 1

Experimental parameter effect on the oxidation reaction of naphthalene to phthalaldehyde.

\begin{tabular}{lcccc}
\hline Entry & $\begin{array}{c}\text { Catalyst loading } \\
(\mathrm{mg} / \mathrm{mmol})\end{array}$ & Oxidant & $\begin{array}{c}\text { Temperature } \\
\left({ }^{\circ} \mathrm{C}\right)\end{array}$ & $\begin{array}{c}\text { GC yield } \\
(\%)\end{array}$ \\
\hline 1 & 0 & $\mathrm{NaIO}_{4}$ & 25 & 0 \\
2 & 25 & $\mathrm{NaIO}_{4}$ & 25 & 11 \\
3 & 50 & $\mathrm{NaIO}_{4}$ & 25 & 24 \\
4 & 75 & $\mathrm{NaIO}_{4}$ & 25 & 41 \\
5 & 100 & $\mathrm{NaIO}_{4}$ & 25 & 43 \\
6 & 150 & $\mathrm{NaIO}_{4}$ & 25 & 39 \\
7 & 75 & $\mathrm{H}_{2} \mathrm{O}_{2}(30 \%)$ & 25 & 5 \\
8 & 75 & $\mathrm{KBrO}_{3}$ & 25 & 45 \\
9 & 75 & $\mathrm{KBrO}_{3}$ & 50 & 37 \\
10 & 75 & $\mathrm{KBrO}_{3}$ & 75 & 32 \\
\hline
\end{tabular}

were detected by GC. In the presence of the catalyst, however, good selectivity toward phthalaldehyde resulted, with the optimum result utilizing $\mathrm{KBrO}_{3}$ as the oxidant (entry 8). Elevating the temperature has an unfavorable impact on the yield, likely as a result of forming higher oxidation products, such as carboxylic acids, which were not characterized. All experiments required vigorous stirring of the reaction mixture because of the multiphase nature of the reactants.

Successful application of ultrasound irradiation in promoting such reactions [25] prompted the evaluation of applying sonic waves in the present method. Employing this technique increased the yield of the desired product to $68 \%$ (Table 2). Reaction yield was studied as a function of ultrasound frequency and irradiation intensity and compared with tunable sonotrode ultrasound intensity levels at $24 \mathrm{kHz}$. As shown in Table 2, at the same irradiation power, frequency does not have a noticeable impact on the reaction yield. The ultrasonic cleaner, however, has a much lower noise.

With the optimized conditions set, a series of arenes were subjected to the oxidation reaction in a multiphase system consisting of substrate, $\mathrm{CH}_{2} \mathrm{Cl}_{2}, \mathrm{H}_{2} \mathrm{O}, \mathrm{CH}_{3} \mathrm{CN}, \mathrm{KBrO}_{3}$, and $\mathrm{MCM}-41-$ $\mathrm{Ru}$. Typical results are shown in Table 3. Treatment of naphthalene ( $1 \mathrm{mmol})$ and $\mathrm{KBrO}_{3}(0.5 \mathrm{~g}, 2.99 \mathrm{mmol})$ in a mixture of solvents $\left(\mathrm{H}_{2} \mathrm{O}, \mathrm{CH}_{2} \mathrm{Cl}_{2}, \mathrm{CH}_{3} \mathrm{CN}, 5 \mathrm{~mL}\right)$ was performed in the presence of MCM-41-Ru composite as the catalyst. Employing sonication in an open vessel at room temperature until the
Table 2

Effect of ultrasound frequency and intensity on the reaction yield.

\begin{tabular}{lcc}
\hline Frequency $(\mathrm{kHz})$ & Max power density $\left(\mathrm{W} / \mathrm{cm}^{2}\right)$ & GC yield $(\%)$ \\
\hline 24 & 110 & 30 \\
24 & 180 & 44 \\
24 & 250 & 69 \\
$50-60$ & 250 & 68 \\
\hline
\end{tabular}

starting naphthalene concentration was undetectable $(1 \mathrm{~h}$, checked by thin-layer chromatography) gave phthalaldehyde as the major product with a yield of $68 \%$. Previously reported methods, however, formed 1,4-naphthoquinone or naphthols as the predominant products [30,31]. It is clear that preventing further oxidation improved the product yield as a result of decreasing the reaction time, compared with our previous report [25].

Anthracene and phenanthrene under the same conditions gave corresponding quinones in good yields (Table 3, entries 2 and 3). Oxidation of chrysene resulted in chrysene-5,6-dione as the main product and, interestingly, also resulted in 2-(2formylphenyl)-1-naphthaldehyde as a by-product $(\mathbf{4 a : 4 b}=$ 94:6). The enhanced ratio of 96:4 in this case may be attributable to a decrease in the reaction time. Perylene, when subjected to this reaction, was resistant, and after $6 \mathrm{~h}$ of irradiation at 50 ${ }^{\circ} \mathrm{C}$, it resulted in no remarkable products. Increasing the oxidant $\left(\mathrm{KBrO}_{3}\right)$ equivalent three-fold resulted in pyrene-4,5-dione being obtained at room temperature with an improved yield of $58 \%$. Further increasing the oxidant to six equivalents under the same conditions afforded pyrene-4,5,9,10-tetraone in $46 \%$ yield (Table 3, entries 5 and 6). Formation of benzoic acid as the main product of biphenyl oxidation was also noteworthy (Table 3, entry 7). Encouraged by these results, we further examined the cleavage of $\mathrm{C}=\mathrm{C}$ double bonds. While trans-stilbene completely converted to benzoic acid and benzil (42:58 ratio), the isomeric 1,1-diphenyl-ethylene produced benzophenone as the main product in $98 \%$ yield.

To clarify the effect of ultrasound irradiation on the oxidation reaction, all reactions were conducted in the absence of ultrasound irradiation. In this case, vigorous mechanical stirring of the reaction mixture for $12 \mathrm{~h}$ yielded similar products (Table 3). Although these results revealed that the MCM-41-Ru catalyst has the advantage of selectivity in the oxidation of

Table 3

Ultrasound assisted MCM-41-Ru nanoparticles catalyzed oxidation of arenes.

\begin{tabular}{|c|c|c|c|c|}
\hline \multirow{2}{*}{ Entry } & \multirow{2}{*}{ Substrate } & \multirow{2}{*}{ Product } & \multicolumn{2}{|c|}{ Isolated yield (\%) } \\
\hline & & & Sonicated $^{a}$ & Non-sonicated ${ }^{\mathrm{b}}$ \\
\hline 1 & Naphthalene & Phthalaldehyde (1a) & 68 & 45 \\
\hline 2 & Anthracene & Anthraquinone (2a) & 92 & 77 \\
\hline 3 & Phenanthrene & 9,10-Phenanthrenequinone (3a) & 95 & 79 \\
\hline \multirow[t]{2}{*}{4} & Chrysene & Chrysene-5,6-dione (4a) & 63 & 43 \\
\hline & & 2-(2-Formylphenyl)-1-naphthaldehyde (4b) & $4^{c}$ & 0 \\
\hline 5 & Pyrene & Pyrene-4,5-dione $(\mathbf{5 a})$ & 58 & $40[24]$ \\
\hline 6 & Pyrene & Pyrene- $4,5,9,10$-tetraone $(\mathbf{6 a})$ & $46^{\mathrm{d}}$ & $33[24]$ \\
\hline 7 & Biphenyl & Benzoic acid (7a) & $90^{\mathrm{e}}$ & 69 \\
\hline \multirow[t]{2}{*}{8} & Trans-stilbene & Benzoic acid (8a) & 42 & 70 \\
\hline & & Benzil (8b) & 58 & 0 \\
\hline 9 & 1,1-Diphenyl-ethylene & Benzophenone (9a) & 98 & 80 \\
\hline
\end{tabular}

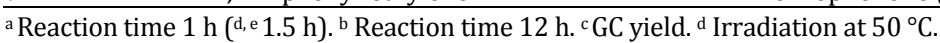




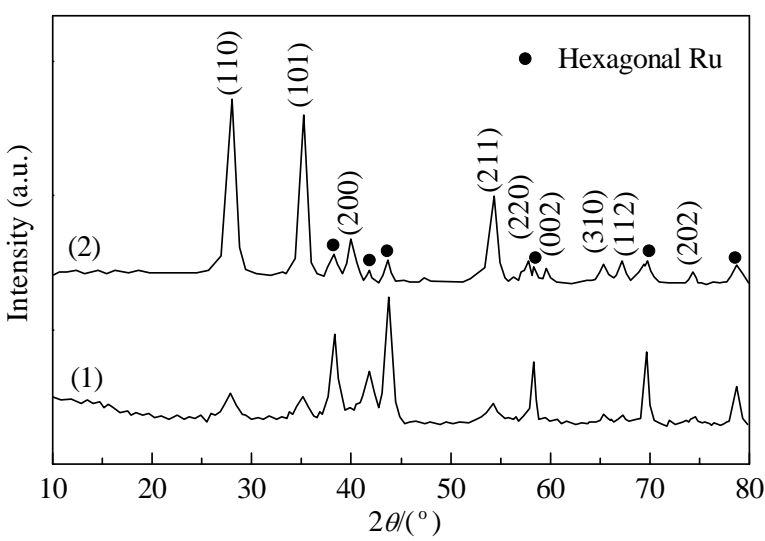

Fig. 4. XRD patterns of the recycled catalyst after the 2nd run (1) and 5 th run (2).

arenes, the application of ultrasound irradiation in promoting the catalyzed oxidation reaction is, however, unavoidable.

To evaluate reusability of the catalyst, oxidation of naphthalene was performed in the presence of the recycled catalyst in successive runs. For reaction runs 1 to 5 , the yields were $68 \%, 68 \%, 59 \%, 53 \%$, and $45 \%$, respectively. After five runs, a $23 \%$ decrease in the efficiency of catalyst was observed. The catalyst itself, however, underwent structural changes during reaction cycles as evident from the XRD patterns of the recycled catalyst of the 2nd and the 5th run. As shown in Fig. 4, characteristic peaks of hexagonal $\mathrm{Ru}$ diminish in favor of newly formed tetragonal $\mathrm{RuO}_{2}$, with the crystallographic planes indexed as (110), (101), (200), (211), (220), (002), (310), (112), and (202) (JCPDS 21-1172).

To evaluate the potential of Ru leaching during the course of the reaction, the MCM-41-Ru composite was removed halfway through the oxidation reaction of biphenyl, and the reaction allowed to continue until the desired reaction time was complete (up to $1.5 \mathrm{~h}$ ). Product yields of $48 \%$ and $49 \%$ were obtained at half and full reaction time, respectively, indicating that no considerable leaching of Ru into the solution occurred. To obtain further insight into the reaction mechanism and understanding better the key role in product selectivity, commercial micro-sized $\mathrm{Ru}(0)$ and $\mathrm{Ru}(\mathrm{IV})$ oxide was used as the catalyst in the oxidation of chrysene under optimized conditions. Although $\mathrm{Ru}(0)$ was unable to catalyze the oxidation reaction, $\mathrm{Ru}(\mathrm{IV})$ oxide resulted in chrysene-5,6-dione (4a) being yield of $11 \%$ with no detectable trace concentrations of $\mathbf{4 b}$ observed by GC analysis. Even though good selectivity resulted, the lower yield may be attributable to the bulk size of $\mathrm{RuO}_{2}$ crystals. Compared with our previous report based on homogeneous $\mathrm{RuO}_{4}$ species, $\mathrm{RuO}_{2}$ nanoparticles showed milder oxidation activity, and complete $\mathrm{C}=\mathrm{C}$ bond cleavage was prevented. Based on these results and that obtained from the XRD analysis of the recycled catalyst, we can deduce that the key reaction mechanism feature is the conversion of surface Ru nanoparticles to the $\mathrm{RuO}_{2}$ species. It has previously been reported that $\mathrm{RuO}_{2}$ can populate species such as molecular oxygen on the (110) surface [32]. In analogy with other reports [33] based on tetrahedral $\mathrm{RuO}_{2}$ species, the proposed mechanism (Scheme 1) may pro-

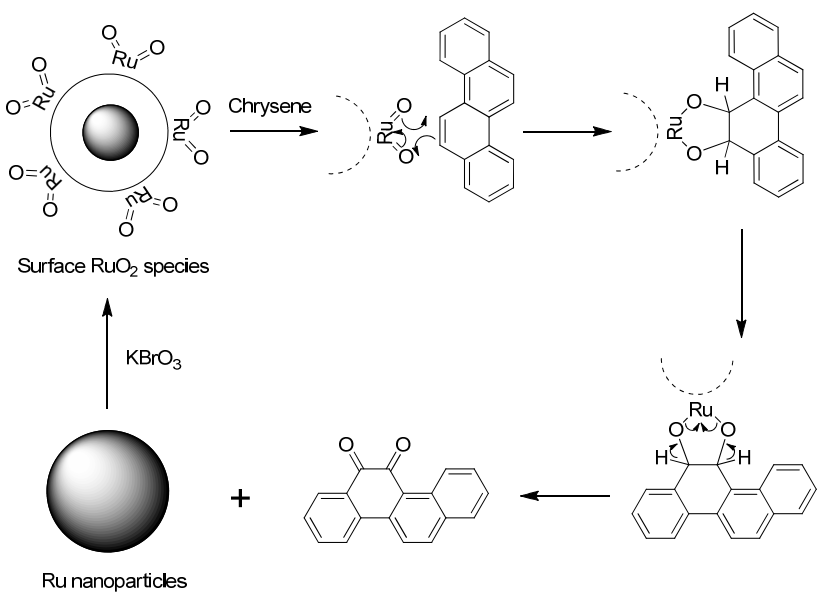

Scheme 1. Reaction mechanism in the selective oxidation of arenes by the conversion of $\mathrm{Ru}$ nanopoarticles to $\mathrm{RuO}_{2}$ species.

vide a pathway in the selective oxidation of arenes, which should be confirmed by future studies.

\section{Conclusions}

MCM-41-Ru was found to be an effective catalyst for the selective oxidation of aromatic compounds in the presence of ultrasound irradiation. The present method improved reaction time at room temperature, however, developing catalysts with improved selectivity for the oxidation of arenes remains a great challenge.

\section{References}

[1] R. Parella, S. A. Babu Naveen, Catal. Commun., 2012, 29, 118.

[2] A. Khalil, A. Fihri, M. Jouiad, R. Hashaikeh, Tetrahedron Lett., 2014, $55,5973$.

[3] E. A. Karakhanov, A. L. Maksimov, E. M. Zakharian, Y. S. Kardasheva, S. V. Savilov, N. I. Truhmanova, A. O. Ivanov, V. A. Vinokurov, J. Mol. Catal. A, 2015, 397, 1.

[4] P. Puthiaraj, W. S. Ahn, Catal. Commun., 2015, 65, 91.

[5] M. Hałupka-Bryl, M. Bednarowicz, B. Dobosz, R. Krzyminiewski, T. Zalewski, B. Wereszczyńska, G. Nowaczyk, M. Jarek, Y. Nagasaki, J. Magn. Magn. Mater., 2015, 384, 320.

[6] J. Kreuter, Adv. Drug Deliver. Rev., 2014, 71, 2.

[7] J. Li, Y. J. Wang, X. J. An, Y. T. Tu, R. J. Liang, K. Wang, G. X. Shen, J. T. Zhu, J. Tao, Nanomed. Nanotechnol. Biol. Med., 2015, 11, 769.

[8] J. Suárez-Cerda, G. A. Nuñez, H. Espinoza-Gómez, L. Z. Flores-López Mater. Sci. Eng. C, 2014, 43, 21.

[9] R. A. Pascal Jr, W. D. McMillan, D. Van Engen., R. G. Eason, J. Am. Chem. Soc., 1987, 109, 4660.

[10] C. Kazunga, M. D. Aitken, Appl. Environ. Microbiol., 2000, 66, 1917.

[11] E. Guthrie-Nichols, A. Grasham, C. Kazunga, R. Sangaiah, A. Gold, J. Bortiatynski, M. Salloum, P. Hatcher, Environ. Toxicol. Chem., 2003, 22,40 .

[12] R. L. Funk, E. R. R. Young, R. M. Williams, M. F. Flanagan, T. L. Cecil, J. Am. Chem. Soc., 1996, 118, 3291.

[13] C. Tintel, J. Terheijden, J. Lugtenburg, J. Cornelisse, Tetrahedron Lett., 1987, 28, 2057.

[14] Y. Li, B. Li, T. Chen, Z. C. Zhou, J. Wang, J. Huang, Chin. J. Catal., 2015, 36, 1086. 


\title{
Graphical Abstract
}

Chin. J. Catal., 2016, 37: 153-158 doi: 10.1016/S1872-2067(15)61001-4

Ruthenium nanoparticles supported on mesoporous MCM-41 as an efficient and reusable catalyst for selective oxidation of arenes under ultrasound irradiation

Alireza Khorshidi *

University of Guilan, Iran

MCM-41 crystallites loaded with Ru nanoparticles were used as heterogeneous catalysts in selective oxidation of arenes under sonic waves. The catalyst active site was found to be $\mathrm{RuO}_{2}$ species formed during the course of reaction.

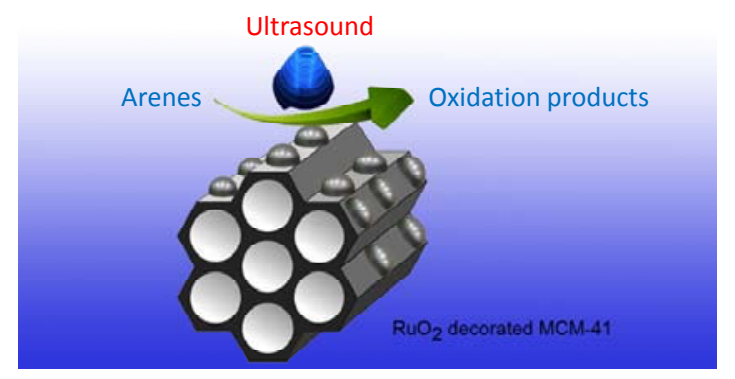

[15] W. J. Mijs, C. R. H. I. De Jonge, Organic Syntheses by Oxidation with Metal Compounds, Springer, New York, 1986.

[16] M. Hudlicky, Oxidations in Organic Chemistry, American Chemical Society, Washington DC, 1990.

[17] Z. M. Zheng, J. P. Obbard, Enzyme Microb. Technol, 2002, 31, 3.

[18] F. G. Oberender, J. A. Dixon, J. Org. Chem., 1959, 24, 1226.

[19] F. X. Webster, J. Rivas-Enterrios, R. M. Silverstein, J. Org. Chem., 1987, 52, 689.

[20] S. Torii, T. Inokuchi, K. Kondo, J. Org. Chem., 1985, 50, 4980.

[21] T. K. M. Shing, V. W. F. Tai, E. K. W. Tam, Angew. Chem. Int. Ed., 1994, 33, 2312.

[22] G. Balavoine, C. Eskenazi, F. Meunier, H. Riviere, Tetrahedron Lett., 1984, 25, 3187.

[23] A. J. Bailey, W. P. Griffith, A. J. P. White, D. J. Williams, J. Chem. Soc., Chem. Commun., 1994, 1833.
[24] J. Hu, D. Zhang, F. W. Harris, J. Org. Chem., 2005, 70, 707.

[25] K. Tabatabaeian, M. Mamaghani, N. O. Mahmoodi, A. Khorshidi, Catal. Commun., 2008, 9, 416.

[26] K. E. Pryor, G. W. Shipps Jr, D. A. Skyler, J. Rebek Jr, Tetrahedron, 1998, 54, 4107.

[27] L. M. Stock, S. H. Wang, Energy Fuels, 1989, 3, 533.

[28] R. Jeyaraman, R. W. Murray, J. Am. Chem. Soc., 1984, 106, 2462.

[29] J. M. Kim, J. H. Kwak, S. Jun, R. Ryoo, J. Phys. Chem., 1995, 99, 16742.

[30] S. Yamazaki, Tetrahedron Lett., 2001, 42, 3355.

[31] H. R. Khavasi, S. S. H. Davarani, N. Safari, J. Mol. Catal. A, 2002, 188, 115.

[32] Y. D. Kim, A. P. Seitsonen, S. Wendt, J. Wang, C. Fan, K. Jacobi, H. Over, G. Ertl, J. Phys. Chem. B, 2001, 105, 3752.

[33] H. C. Liu, E. Iglesia, J. Phys. Chem. B, 2005, 109, 2155.

\section{中孔MCM-41负载Ru纳米粒子催化剂用于超声辐射下芳烃选择氧化反应}

\author{
Alireza Khorshidi ${ }^{*}$ \\ 桂兰大学理学院化学系, 桂兰, 雷什特, 伊朗
}

摘要: 以中孔MCM-41为载体制得均一分散的粒径约 $5 \mathrm{~nm}$ 的 Ru纳米粒子催化剂 $M C M-41-\mathrm{Ru}$, 采用电感耦合等离子体、透射 电镜、能量散射谱、 $X$ 射线衍射和 $\mathrm{N}_{2}$ 吸附-脱附法对其进行了表征, 并将其作为可重复使用高效催化剂用于超声辅助芳烃选 择氧化反应. 结果表明, 在超声辐射和 $\mathrm{KBrO}_{3}$ 为氧化剂条件下, MCM-41-Ru催化剂加速了氧化反应, 并以较高产率得到目 的产物. 回收的催化剂用于下次反应时活性保持不变, 但其活性中心性质发生变化.

关键词: 纳米粒子; 超声; 钉; 芳烃氧化; MCM-41

收稿日期: 2015-10-09. 接受日期: 2015-10-24. 出版日期: 2016-01-05.

*通讯联系人. 电话: +98-911 339 7159; 传真: +98-13 333332 62; 电子信箱: khorshidi@guilan.ac.ir

本文的英文电子版由Elsevier出版社在ScienceDirect上出版(http://www.sciencedirect.com/science/journal/18722067). 